\title{
PROXIMATE AND PHYTOCHEMICAL COMPOSITIONS OF SOME BROWSE PLANT SPECIES OF SOUTHEASTERN NIGERIA
}

(Received 12, November 2007; Revision Accepted 4, February2009)

\begin{abstract}
The proximate and phytochemical composition of some browse plant species were studied at the rainforests at Oban National Park and Umudike, Nigeria to determine their suitability as feeding material for wild and domestic animals. Questionnaire was served to 50 individuals who are either hunters or rear upto six goats or sheep within Umudike and Oban National Park enclave to know the plant species fed upon by wild animals and domestic animals. Two 10 - hectare blocks were laid at Oban National Park and the rain forest at Umudike. Leaves of all the plant species eaten by vertebrate animals within the 10 hectare blocks were collected and identified to species level at the Forest Herbarium, Forestry Research Institute at Jericho, Ibadan, Nigeria. Out of 27 plant species eaten by animals, 17 plant species were selected at random for study of their leaves proximate, phytochemical and mineral composition. It was observed that moisture content ranged between 8.08 and 11.10 per cent. The dry matter ranged between 88.90 and 91.92 per cent. The percent crude protein was highest in Uvaria chamae $(21.88 \%)$ and least in Andropogeon tectorum (10.50\%). The crude fat ranged from 1.38 percent in Gmelina arborea to 10.26 in U. chamae. The crude fibre was highest in Ficus exasperata (38.04\%) and least in U.chamae with 8.96 per cent. The percent ash ranged from 5.98 to 9.44 . The carbohydrates ranged from 37.76 to 54.56 per cent while the energy ranged from 226.08 to 387.30 . In all of the studied plant species, the percent alkaloid, saponine, flavanoid, tannin and steroid were often less than 10 per cent. However, the Hydrogen cynide ranged from 0.05 in Uvaria chamae to 0.93 in Aspilia africana. The percent Sodium, Potassium, Calcium, Magnesium, Phosphorus, Iron, Zinc, Copper, Lead, Cadmium and Manganese were often less than 5.0 percent. Mercury was in trace amount. Based on the contents of the leaves, these plants: Allophylus africanus, Costus afer, Uvaria chamae, Myrianthus arboreus, Carpolobia lutea, Ficus exasperata and Hannoa klaineana having upto $10 \%$ per cent crude protein, 5.00 percent crude fat and high palatability should be used in the establishment of fodder bank. The use of leaves of Treculia africana as fodder should be discouraged as it contains little quantity of Cadmium and Chromium which could have cumulative adverse effects.
\end{abstract}

KEYWORDS: Fodder, proximate and phytochemical compositions, Cadmium, chromium.

\section{INTRODUCTION}

The tropical rainforest of Nigeria occurs at the southern part of the country between latitudes $5^{0} 30^{1}$ and $6^{\circ} 40^{1} \mathrm{~N}$ and longitudes $3^{\circ} 45^{1}$ and $9^{\circ} 55^{1} \mathrm{E}$ (Onochie, 1979). The rainforest is made up of a complex mixture of woody plant species of which 120 woody plant species have been enumerated per hectare at Omo Biosphere Reserve, Nigeria (Dike, 1992; 2003). These plant species have various uses (Burkill, 1985). Herbivores at national parks, wildlife sanctuaries, forest reserves and domesticated herbivores at various institutions and homes feed on twigs and leaves of some of these plant species. Observations at Omo Biosphere Reserve, Kainji Lake National Park and Yankari National Park, Nigeria revealed that Loxodonta africana cyclotis (elephants) fed on the leaves of Margretaria discoidea, Monodora myristica and Detarium macrocarpum. During lean periods, elephants in addition to feeding on leaves, fed also on the bark of Adansonia digitata and Tetrapleura tetraptera (Jones, 1956; Milligan et al; 1982; Ngoka and Dike, 2008). Black, (1992) working at Portland, Oregon reported that porcupines and black bears fed on barks and sapwoods of conifers. However, the black bears showed preference for the barks of Douglas fir, western larch and Engelmann spruce. Devendra and McLeroy, (1982) working at Mexico recorded that 83 per cent of 1728 bites of goats were for browse and 17 percent were for grasses. Brinckman and deLeeuw, (1979); Milligan and Sule, (1982) working in
Northern Nigeria reported that browse plants have higher percent contents of protein, potassium, calcium, phosphorus and magnesium than most grasses. Milligan et al; (1982) reported that out of 40 plants they observed, 37.5 percent including Afromosia laxiflora were avoided; 35 percent were occasionally fed upon while 27.5 per cent were always consumed when seen. It appears that nutrient elements could be deficient or toxic in some plant species. Norton (1994) recorded that leaves of Acacia aneura contain condensed tannins (Proanthocyanidins) and insoluble oxalates. These contents contribute to the poor acceptability of some leaves by animals. Irrespective of the numerous leaves produced by various plant species per hectare, these herbivores have preferences for leaves and barks of some plant species.

To achieve near efficient feeding, these wild herbivores search for the leaves of desirable plant species within the forest and nearby buffer zones. There is paucity of literature on the proximate and phytochemical compositions of leaves of these plant species which these animals feed upon. Emphasis had been mainly on the proximate composition of some grasses such as Andropogon tectorum, Cynodon dactylon, Panicum maximum and Pennisetum purpureum (Chheda, 1973; Crowder, 1973; Olubajo, 1973; Devendra and McLeroy, 1982) and few climbers such and Centrosema pubescens and Calopogonium muconoides (Ahamefule et al., 2000) and few trees such ad Ficus spp; Erythrina spp, Prosopis cineraria, Gliricidia 
spp and Leuceana leucocephala (Devendra, 1991). These grasses and climbers when well managed performed well during the wet season. Their yield was low during the dry season and these grasses could be burnt accidentally during the dry season. Also, it is difficult to germinate, establish and maintain grasses under the interlocking branches of trees in National Parks within the rainforest ecosystems. Moreover, there is the problem of seeds of pioneer plant species stored in the soil seed bank (Whitmore, 1983) and seeds of unwanted plant species germinating and the resultant seedlings invading the desirable grasses within large tree fall gaps. However, it is only the first three listed tree species above that are indigenous. In some parts of the National Parks such as Yankari National Park within the savanna ecological zone of Nigeria, many animals suffer during the dry season especially when the grasses have been burnt. Animals were more at river banks and valleys where some trees were growing. Some hungry wildlife could roam outside the buffer zone in search of food and either picks up large quantity of poisonous fodder such as Leucaena leucocephala containing mimosine (Devendra and McLeroy, 1982; Gupta et al; 1991) or Acacia spp containing Cyanogenic glucosides and Fluoroacetate which are harmful to animals. Norton (1994) recorded that the ingestion of hydrolysable tannins is often very fatal especially to ruminants. The knowledge of the composition of the leaves is essential to enable the planting of valuable and non-toxic indigenous fodder plant species where they are needed. Adequate diet has good effects on the vitality, health and appearance of the animals that consumed it. Ibeawuchi and Akinsoyinu, (1989) recorded that Zebu cow's milk protein depends on it's protein intake. There is the need to have fodder banks comprising plant species with high quantity and quality of desirable nutrients in their leaves to minimize poor nutrition and nutritional stress to these animals especially during lean periods. These wild animals are not supposed to take adequate care of their nutrition if they are to appear healthy and good looking to visitors. Presumably, some of these wild animal in National Parks could provide few other services such as milk production if properly fed and cared for. This paper reports the proximate and phytochemical compositions of leaves of 17 plant species from the rainforest at Umudike, and Oban National Park Nigeria. The result would be useful to park managers, animal producers and institutions concerned with the development of the quality of both wild and domesticated animals.

\section{MATERIALS AND METHODS}

\section{Study Area}

The study was carried out at Oban National Park, Cross River State, and the rainforest at Umudike, Abia State both in southeastern Nigeria (Figure. 1). Oban National Park has been described by King, (1996). Oban National Park is part of Oban Forest Reserve which was converted to a National Park. Oban National Park lies between latitudes $04^{\circ} 45^{1}$ and $05^{\circ} 45^{1} \mathrm{~N}$ and longitudes $03^{\circ} 20^{1}$ and $08^{\circ} 50^{1} \mathrm{E}$. Umudike lies between latitudes $05^{\circ} 27^{1}$ and $05^{\circ} 32^{1} \mathrm{~N}$ and longitudes $07^{\circ} 30^{1}$ and $07^{\circ} 50^{1} \mathrm{E}$. The climate of southeastern Nigeria is of the equatorial type. The top soil minimum and maximum temperatures were $16^{\circ} \mathrm{C}$ and $45^{\circ} \mathrm{C}$, respectively (Dike, 1992). There are two seasons: a wet and a dry season. The wet season starts from mid-March and ends in midNovember. The total annual rainfall ranges between 1500 and $3000 \mathrm{~mm}$. There are two peaks in the monthly rainfall in the months of June/July and September. The dry season continues till the mid-March of the following year. During the peak of the dry season, many trees such as Ceiba pentandra shade most of their leaves (Dike, 2001). The dusty harmattan wind blows intermittently during the months of December and January. The relative humidity is high and above 60 percent at nights. The relative humidity could be as low as 45 per cent at the day time during the peak of the dry harmattan period. 


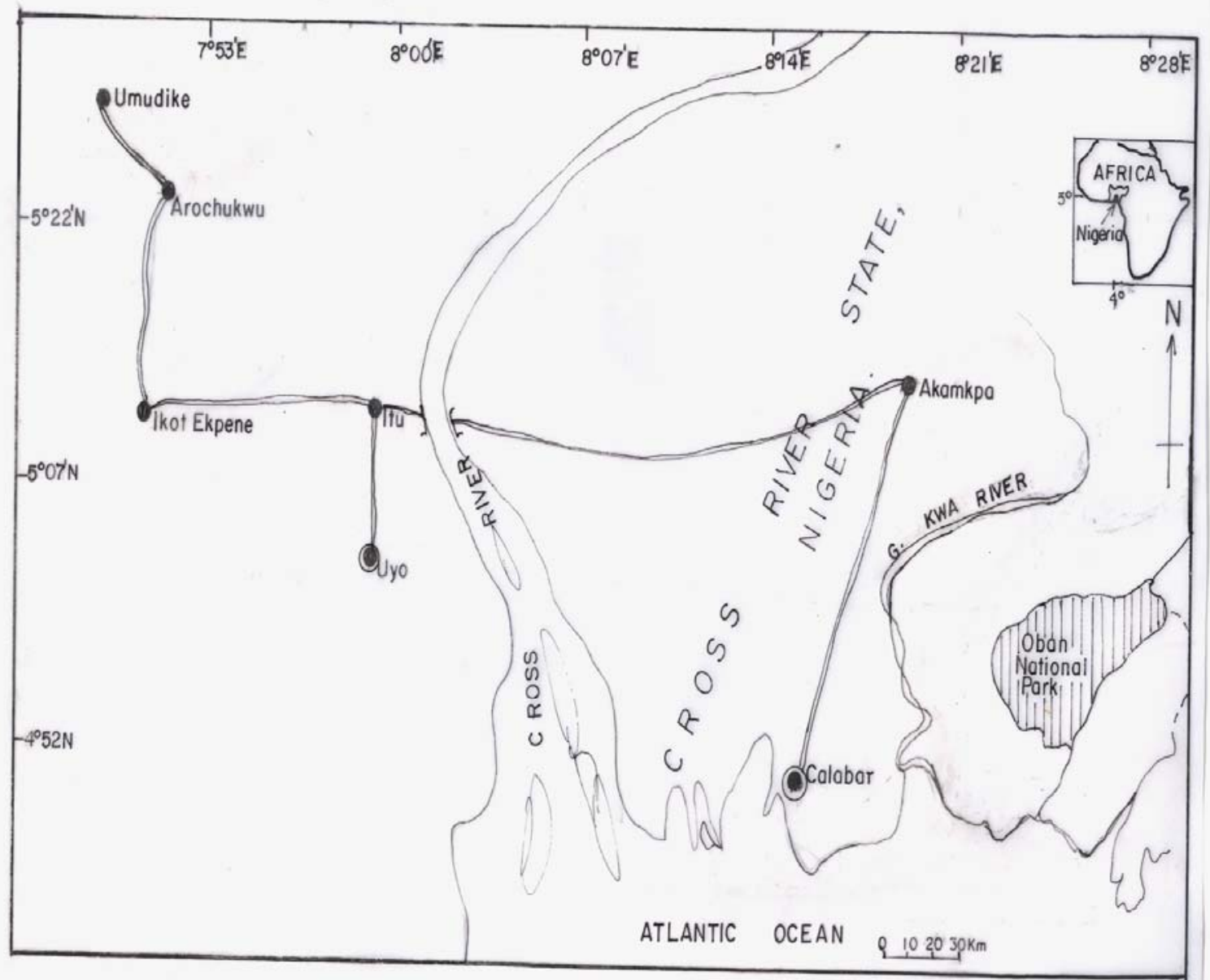

Figure 1: A sketch map of Southeastern Nigeria showing Umudike Town and Oban National Park. (Adapted from Road Map of Nigeria, Federal Surveys, Nigeria, 1977)

The vegetation is tropical rainforest (White, 1983). The original vegetation has been destroyed by farmers and loggers. Presently, in many places previously mapped as forest, secondary forest regrowths in various degrees of degradation occur. The abundant tree species within the secondary forest regrowth are Anthonotha macrophylla, Dialium guineense, Elaeis guineensis and Pentaclethra macrophylla. The soil is deep, well drained sandy - clay loam and without stones in most places. The soil parent material is the Pre-cambrian Basement Complex.

\section{Methodology}

Questionnaire was served to 50 individuals who are either hunters or rear upto six goats or sheep within Umudike and at the buffer zone of Oban National Park to ascertain the names of plant species browsed upon by herbivorous animals. Two 10 hectare blocks were also marked out within Umudike rainforest and Oban National Park and the leaves of all plants species browsed upon by wild animals within the two 10 hectare blocks were identified to species level. Out of the 28 plant species listed as being eaten by animals, 17 plant species were selected at random for the analysis of their proximate, phytochemical and mineral compositions. The plant species studied were Allophylus africanus, Andropogon tectorum, Anthocleista djalonensis, Aspilia africana, Carpolobia lutea, Costus afer, Dactyladenia barteri, Ficus exasperata, Gmelina arborea, Hannoa klaineana, Manniophyton fulvum, Myrianthus arboreus, Pennisetum purpureum, Ricinodendron heudelottii, Treculia africana, Uvaria chamae and Vitex doniana. The distribution of these plant species have been described by Hutchinson and Dalziel, (1954 - 1972). The plant species were identified at the Herbarium at the Department of Forestry and Environmental Management, University of Agriculture, Umudike using the keys in the Flora of West Tropical Africa (Hutchinson and Dalziel, 1954 - 1972). Pressed samples of these plant species were taken to the Forest Herbarium at the Forestry Research Institute of Nigeria, Ibadan where the names of these plant species were confirmed.

The leaves of the plant species were collected from the 78 - year old rainforest regrowth at the University of Agriculture, Umudike, Nigeria at 12.00 noon on June, 142008 and at Oban Forest Reserve. The leaves of each plant species were weighed and then dried in a Fisher Isotemp Oven (Model 175) at $65^{\circ} \mathrm{C}$ for 6 hours. Each of the dried leaves were ground into powder and stored in a numbered and labeled bottle. Samples for analysis of each plant species were collected from the specific bottle. For each sample, the moisture content, crude fat, crude protein, and ash content and minerals were determined as described by the Association of Official Analytical Chemist (AOAC), (2000); Grubb et al; (1994) and James, (1995). The food energy was calculated using the formula: $\mathrm{FE}=(\% \mathrm{CP} x$ 4) $\times(\% \mathrm{EE} \times 9) \times(\% \mathrm{CHO} \times 4)$. 
Where, FE represents food energy,

EE represents ether extracts, $\mathrm{CP}$ represents crude protein and

$\mathrm{CHO}$ represents carbohydrates.

Crude fibre was estimated as was described by Entwistle and Hunter (1994). The percent carbohydrate was obtained using the formula:

Carbohydrate $(\mathrm{CHO} \%)=100-(\% \mathrm{CP}+\% \mathrm{CF}+\%$ Ash + \%Esther Extract)

\section{RESULTS AND DISCUSSIONS}

All of the studied plant species contained moisture and mineral elements. The percent moisture content varied slightly within species and ranged from 8,06 in Aspilia africana to 9.98 in Manniophytum fulvum. The per cent dry matter ranged from 90.02 to 91.94 . The per cent dry matter of $91.82 ; 91.92$ and 91.94 obtained by the three grasses Pennisetum purpureum, Andropogon tectorum and Aspilia Africana, respectively were higher than either 24.3 per cent recorded for eight weeks grown Panicum maximum or 38.3 per cent recorded for 52 weeks grown Pennisetum purpureum (Devendra and McLeroy, 1982). The grasses from where the leaves were collected for analyses have grown for over 60 weeks and have higher dry matter. The record of Devendra and McLeroy, (1982) revealed that the dry matter of grasses such as Cynodon dactylon and Pennisetum purpureum increased with increasing number of weeks of growth. The per cent dry matter for the tree species agreed with the 91.3 and 92.0 per cent recorded for the leaves of Acacia auriculiformis and Acacia cavenia, respectively (Devendra and McLeroy, 1982).
Aspillia africana, Andropogon tectorum and Pennisetum purpureum had per cent crude protein of less than 12.0 per cent while the tree species each had values of over 13.60 per cent (Table 1). The observation agreed with the record of Milligan and Sule, (1982) that browse plants have higher per cent crude protein than most grasses. However, the percent crude protein values for the grasses were higher than 4.57 per cent obtained for Panicum maximum at Umudike (Ahamefule et al., 2000). The crude protein for some grasses decreased with increasing number of weeks after planting. Of interest is Costus afer, a shrub having crude protein of 16.80 per cent. In the family Euphorbiaceae, crude protein for the studied plant species had the same value of 13.65 per cent; in the families Moraceae and Poaceae there were slight differences of between 13.65 and 18.55 per cent and in the family Verbanaceae there were minor differences of between and 19.60 (Table 1). The family Polygalaceae had the highest value of 23.80 per cent.

The per cent ether extract ranged from 1.38 in Gmelina arborea to 10.26 in Uvaria chamae (Table 1). The per cent ether extract of 1.46; 2.48 and 3.84 for the three grasses are similar to 1.47 and 4.2 per cent recorded for Talinum triangulare and Corchorus olitorius, respectively (Badra, 1993); however, the 5.7 value for the tree Acacia auriculiformis was low for most tree species which had over 5.96 per cent (Table 1). The per cent crude fibre ranged from 6.02 in Myrianthus arboreus to 38.04 in Ficus exasperata. The per cent ash was below 10.0 in all of the studied plant species and ranged from 4.96 in Aspilia africana to 9.44 in Treculia africana. The per cent carbohydrate had the least value in Ficus exasperata (34.75) and the highest value of 60.47 in Aspilia africana (Table 1) 
Table 1: The Proximate and Phytochemical Composition of 17 plant species studied at Umudike, Nigeria

\begin{tabular}{|c|c|c|c|c|c|c|c|c|c|c|c|c|c|c|c|c|c|c|c|}
\hline \multirow{2}{*}{$\begin{array}{l}\text { Families } \\
\text { Species }\end{array}$} & \multirow{2}{*}{$\begin{array}{l}\text { Annon } \\
\text { aceae } \\
U . \\
\text { chama } \\
e\end{array}$} & \multirow{2}{*}{$\begin{array}{l}\text { Astera } \\
\text { ceae } \\
\text { A. } \\
\text { african } \\
\text { a }\end{array}$} & \multicolumn{2}{|c|}{ Euphorbiaceae } & \multirow{2}{*}{$\begin{array}{l}\text { Logani } \\
\text { aceae } \\
\text { A. } \\
\text { djalon } \\
\text { ensis }\end{array}$} & \multirow[b]{2}{*}{$\begin{array}{l}\text { F.exasp } \\
\text { erata }\end{array}$} & \multirow[b]{2}{*}{$\begin{array}{l}\text { M. } \\
\text { arbore } \\
\text { us }\end{array}$} & Иoraceae & \multicolumn{2}{|c|}{ Poaceae } & \multirow{2}{*}{$\begin{array}{l}\text { Polyga } \\
\text { laceae } \\
\text { C. } \\
\text { lutea }\end{array}$} & \multirow{2}{*}{$\begin{array}{l}\begin{array}{l}\text { Rosac } \\
\text { eae }\end{array} \\
D . \\
\text { barteri }\end{array}$} & \multirow{2}{*}{$\begin{array}{l}\begin{array}{l}\text { Sapind } \\
\text { aceae }\end{array} \\
\text { A.afric } \\
\text { anus }\end{array}$} & \multirow{2}{*}{$\begin{array}{l}\text { Simar } \\
\text { oubac } \\
\text { eae } \\
H . \\
\text { klaine } \\
\text { ana } \\
\end{array}$} & \multicolumn{2}{|c|}{ Verbanaceae } & \multirow{2}{*}{$\begin{array}{l}\text { Zingiberac } \\
\text { eae } \\
\text { C. afer }\end{array}$} & \multicolumn{2}{|c|}{ Range } \\
\hline & & & $\begin{array}{l}M . \\
\text { fulvum }\end{array}$ & $\begin{array}{l}R . \\
\text { heudel } \\
\text { otic }\end{array}$ & & & & $\begin{array}{l}T . \\
\text { african } \\
a \\
\end{array}$ & $\begin{array}{l}\text { A. } \\
\text { tectoru } \\
m \\
\end{array}$ & $\begin{array}{l}\text { P.purp } \\
\text { ureum }\end{array}$ & & & & & $\begin{array}{l}\text { G. } \\
\text { arbore } \\
a\end{array}$ & $\begin{array}{l}V . \\
\text { donian } \\
a\end{array}$ & & & \\
\hline \multicolumn{20}{|l|}{ Parameters } \\
\hline$\%$ moisture content & 8.62 & 8.06 & 9.98 & 8.12 & 8.6 & 10.22 & 9.28 & 8.42 & 8.08 & 8.18 & 8.16 & 8.10 & 8.54 & 8.36 & 8.66 & 8.08 & 8.34 & 8.06 & 10.22 \\
\hline$\%$ dry matter & 91.38 & 91.94 & 90.02 & 91.88 & 91.4 & 89.78 & 90.72 & 91.58 & 91.58 & 91.82 & 91.84 & 91.90 & 91.46 & 91.64 & 91.34 & 91.92 & 91.66 & 89.78 & 91.94 \\
\hline$\%$ Crude protein & 21.88 & 8.75 & 13.65 & 13.65 & 15.3 & 13.65 & 18.20 & 18.55 & 18.55 & 11.55 & 23.80 & 18.90 & 20.56 & 13.65 & 19.60 & 15.75 & 16.80 & 8.75 & 23.80 \\
\hline$\%$ ether extract & 10.26 & 3.84 & 2.16 & 7.82 & 9.2 & 7.12 & 5.96 & 3.06 & 3.06 & 1.46 & 8.12 & 3.04 & 7.78 & 8.96 & 1.38 & 3.14 & 2.12 & 1.38 & 10.26 \\
\hline$\%$ Crude fibre & 8.96 & 13.92 & 35.12 & 22.46 & 2.7 & 38.04 & 6.02 & 19.84 & 19.84 & 26.72 & 13.94 & 26.22 & 10.25 & 10.38 & 17.94 & 11.08 & 17.44 & 2.7 & 38.04 \\
\hline$\%$ ash & 7.04 & 4.96 & 8.62 & 5.84 & 6.47 & 6.44 & 5.98 & 9.44 & 9.44 & 8.12 & 6.32 & 5.98 & 6.84 & 7.44 & 7.42 & 7.04 & 6.98 & 4.96 & 9.44 \\
\hline$\%$ Carbohydrate & 51.86 & 60.47 & 40.45 & 42.11 & 17.0 & 34.75 & 54.56 & 49.11 & 49.11 & 43.97 & 39.66 & 37.76 & 54.56 & 51.41 & 45.00 & 54.91 & 48.32 & 17.0 & 60.47 \\
\hline Energy & 387.30 & & 235.84 & & & 257.30 & 344.68 & 298.18 & 293.18 & 235.22 & 326.92 & 254.00 & 370.50 & 339.08 & 270.82 & 310.90 & 279.56 & 235.22 & 387.3 \\
\hline$\%$ alkaloid & 9.42 & 0.76 & 0.56 & 1.42 & 1.11 & 0.46 & 3.12 & 1.26 & 1.26 & 0.56 & 7.02 & 1.46 & 3.48 & 6.12 & 1.32 & 5.64 & 2.24 & 0.46 & 9.42 \\
\hline$\%$ saponine & 0.28 & 1.14 & 0.88 & 0.66 & 0.54 & 1.24 & 0.50 & 1.14 & 1.14 & 0.24 & 0.32 & 0.22 & 0.44 & 0.28 & 0.38 & 0.42 & 0.34 & 0.22 & 1.24 \\
\hline$\%$ flavanoid & 1.44 & 1.18 & 0.66 & 0.34 & 1.01 & 0.26 & 0.46 & 0.34 & 0.34 & 0.18 & 2.26 & 0.92 & 2.86 & 0.86 & 1.22 & 3.04 & 0.18 & 0.18 & 2.86 \\
\hline$\%$ tannis & 0.12 & 0.11 & 0.24 & 0.27 & 0.18 & 0.16 & 0.04 & 0.38 & 0.38 & 0.16 & 0.54 & 0.12 & 0.66 & 0.62 & 0.32 & 0.48 & 2.16 & 0.04 & 0.66 \\
\hline $\mathrm{HCN}(\mathrm{mg} / 100 \mathrm{~g})$ & 0.05 & 0.93 & 1.16 & 2.23 & 0.90 & 0.63 & 0.62 & 0.92 & 0.92 & 0.33 & 0.75 & 0.09 & 0.06 & 0.86 & 0.08 & 0.59 & 0.59 & 0.05 & 0.59 \\
\hline $\begin{array}{l}\text { \% Steriod } \\
(\mathrm{mg} / 100 \mathrm{~g})\end{array}$ & 0.06 & 0.02 & 0.02 & 0.06 & 0.15 & 0.02 & 0.02 & 0.03 & 0.03 & 0.01 & 0.06 & 0.03 & 0.01 & 0.06 & 0.02 & 0.03 & 0.06 & 0.01 & 0.06 \\
\hline $\mathrm{Mg}$ & 30 & 23.18 & 12.56 & 13.86 & 42.0 & 21.64 & 38.60 & 38.24 & 38.24 & 38.00 & 22.90 & 22.40 & 21.00 & 24.60 & 14.6 & 28.2 & 16.40 & 12.56 & 42.0 \\
\hline K & 12.20 & 13.22 & 13.86 & 11.24 & 35.0 & 12.70 & 13.20 & 22.04 & 22.04 & 10.46 & 13.12 & 14.00 & 10.94 & 11.08 & 9.82 & 9.66 & 13.20 & 9.66 & 22.04 \\
\hline $\mathrm{Na}$ & 630 & 202.40 & 341 & 168.30 & 214 & 384.6 & 264.20 & 366.00 & 366.00 & 218 & 186 & 138.0 & 700 & 172 & 162.00 & 202.00 & 264.00 & 132 & 700 \\
\hline$P$ & 25 & 21.86 & 24.20 & 16.12 & 25.0 & 19.82 & 18.14 & 18.60 & 18.60 & 8.65 & 10.18 & 9.42 & 1.90 & 11.96 & 18.32 & 13.11 & 9.88 & 1.90 & 25.0 \\
\hline $\mathrm{Fe}$ & 500 & 216.04 & 524 & 238.40 & 240 & 286.44 & 202.84 & 482.00 & 482.00 & 131.00 & 84.00 & 101.00 & 575 & 660.0 & 133.00 & 158.00 & 326.00 & 834 & 660 \\
\hline $\mathrm{Zn}$ & 11.64 & 3.08 & 6.92 & 2.16 & 6.88 & 3.10 & 8.42 & 6.88 & 6.88 & 9.30 & 21.31 & 8.65 & 20.40 & 12.54 & 9.86 & 11.24 & 6.80 & 2.16 & 21.31 \\
\hline $\mathrm{Cu}$ & 1.59 & 0.84 & 0.46 & 1.94 & 1.50 & 0.41 & 0.74 & 0.58 & 0.58 & 0.83 & 0.99 & 1.41 & 2.82 & 1.13 & 1.68 & 1.70 & 2.44 & 0.41 & 2.82 \\
\hline $\mathrm{Pb}$ & 1.47 & 0.16 & 0.12 & 0.21 & 0.12 & 0.11 & 1.31 & 0.04 & 0.04 & 1.94 & 4.11 & 1.20 & 3.64 & 2.14 & 1.34 & 1.57 & 0.28 & 0.04 & 4.11 \\
\hline Co & 0.03 & 0.02 & 0.02 & 0.02 & 0.02 & 0.02 & 0.02 & 0.02 & 0.02 & 0.01 & 0.01 & 0.01 & 0.01 & 0.01 & 0.01 & 0.02 & 0.08 & 0.01 & 0.08 \\
\hline $\mathrm{Ni}$ & 0.00 & 0.02 & 0.14 & 0.06 & 0.04 & 0.03 & 0.03 & 0.04 & 0.04 & 0.01 & 0.00 & 0.00 & 0.00 & 0.00 & 0.00 & 0.01 & 0.06 & 0.00 & 0.14 \\
\hline $\mathrm{Cr}$ & 0.00 & 0.02 & 0.00 & 0.04 & 0.00 & 0.00 & 0.01 & 0.00 & 0.00 & 0.00 & 0.00 & 0.00 & 0.00 & 0.00 & 0.00 & 0.00 & 0.04 & 0.00 & 0.04 \\
\hline $\mathrm{Mn}$ & 0.00 & 0.00 & 0.01 & 0.02 & 0.01 & 0.00 & 0.00 & 0.02 & 0.02 & 0.00 & 0.00 & 0.00 & 0.00 & 0.00 & 0.00 & 0.00 & 0.00 & 0.00 & 0.02 \\
\hline $\mathrm{Cd}$ & 0.04 & 0.08 & 0.16 & 0.04 & 0.05 & 0.16 & 0.05 & 0.14 & 0.14 & 0.06 & 0.01 & 0.01 & 0.00 & 0.00 & 0.01 & 0.01 & 0.02 & 0.00 & 0.10 \\
\hline $\mathrm{Se}$ & 0.01 & 0.02 & 0.01 & 0.04 & 0.01 & 0.00 & 0.00 & 0.04 & 0.04 & 0.01 & 0.00 & & & & & & 0.05 & 0.00 & 0.05 \\
\hline $\mathrm{Hg}$ & 0.01 & 0.11 & 0.30 & 0.16 & 0.16 & 0.01 & 0.00 & 0.24 & 0.24 & 0.01 & 0.00 & & & & & & 0.00 & 0.00 & 0.30 \\
\hline & 0.00 & 0.00 & 0.00 & 0.00 & 0.00 & 0.00 & 0.00 & 0.00 & 0.00 & 0.00 & 0.00 & 0.00 & 0.00 & 0.00 & 0.01 & 0.01 & 0.01 & 0.00 & 0.01 \\
\hline
\end{tabular}


The per cent alkaloid were 2.24, 3.12, 3.48,5.64, 6.12, 7.02 and 9.42 in Costus afer, Myrianthus arboreus, Allophylus africanus, Vitex doniana, Hannoa klaineana, Carpolobia lutea and Uvaria chamae. Other studied plant species had values of less than 1.5 percent (Table 1). The per cent saponine was less that 1.3 per cent. The per cent flavanoid was less than 1.5 except in Carpolobia lutea having (2.25); Allophylus africanus $(2.86 \%)$ and Vitex doniana (3.04\%). The per cent tannins was less than 0.80 except in Costus afer having 2.16. The least value of 0.04 per cent tannins was obtained by Myrianthus arboreus. In this study, the new leaf flush was used. The per cent hydrogen cynide was less than 1.4 per cent in all the species except Ricinodendon heudelotii having 2.23. The steroid was less than 0.10 per cent.

The per cent calcium, magnesium, iron and zinc were very low. The per cent calcium ranged between 12.56 in Manniophyton fulvum and 38.60 in Myrianthus arboreus (Table 1). It was only four plant species Pennisetum purpureum, Andropogon tectorum, Treculia africana and Myrianthus arboreus that had upto 33.40 per cent calcium. Low values of calcium has been recorded for Corchorus olitorius, Celosia argentea, Talinum triangualare and Amaranthus caudatus (Faboya 1983; Badra, 1993). The per cent magnesium was least in Vitex doniana (9.66\%) and highest in Treculia africana (22.04). The per cent potassium sodium, phosphorus and iron in each of the samples were each less than 40 per cent.

The per cent zinc in each sample was less than 3.0 per cent. It was only in Carpolobia lutea and Allophylus africanus that the per cent copper were 4.11 and 3.64, respectively. Other studied plant samples had values less than 3.0 per cent. The per cent lead had the higher value of 0.08 in Costus afer. The Costus afer was near a stream. Other samples had values of 0.03, 0.02 or 0.01 . The percent Cobalt was highest in Manniophytum fulvum with 0.14 per cent. Other samples had values of 0.07 per cent. The per cent Nickel, Cadmium and Chromium were less than 0.05 percent in all of the studied plant species and were within between 10 and 20 ug daily requirement for human beings (Nielsen, 2001). Nielsen (2001) attributed depressed growth in goats to cadmium and nickel deprivation. The Selenium and Mercury were in trace amounts. According to Nielsen (2001) inorganic Selenium is fed to livestock in the United State. In some countries, such as China, Selenium contents in corn, rice and soybeans vary from one part of the country to another. However, Nielsen (2001) recorded that wild animal need selenium to increase their cancer protection.

\section{CONCLUSTION AND RECOMMENDATIONS}

A combination of any of these plant species Allophyllus africanus, Anthocleista djalonensis, Carpolobia lutea, Dactyladenia barteri, Ficus exasperata, Gmelina arborea, Hannoa klaineana, Myrianthus arboreus, Ricinodendron heudelotii, Uvaria chamae and Vitex doniana having upto 10 per cent crude protein, 5 per cent crude fat and little per cent tannins in their leaves should be used in producing fodder banks. The apical shoot of these plant species should be cut periodically to enable numerous branches to be produced. The fodder banks when properly located would minimize the time animals use to search for adequate fodder. Visitor would be happy viewing these animals. Three strata should be formed depending on the height of the targeted feeder on the leaves. Treculia africana having 0.04 and 0.02 per cent cadmium and chromium, respectively should rarely be used as a composition of a fodder bank. The metals could have adverse cumulative effects. It is recommended that some animals such as Syncerus nanus (buffalo) and Tragaphylus scriptus (kob) that fed on desirable browse plant should in addition to their aestatic value be taught how to dance while Cephalophus maxwelli (duiker) should produce some quantity of meat and milk. With time, these animals could be domesticated. Universities should teach park managers and farmers how to propagate these plants both by vegetative methods and by seed. These grasses Aspilia africana, Andropogon tectorum and Pennisetum purpureum should be cut, dried and fed to animals that danced during peak visiting time.

\section{REFERENCES}

A. O. A. C., 2000. Official Methods of Analysis International $\left(17^{\text {th }}\right.$ edition).Association of Official Analytical Chemist, Washington, D. C. USA.

Ahamefule, F. O., Ibeawuchi, J. A. and Ejiofor, C. A, 2000. A comparative study of the constituents of the milk of cattle, sheep and goats in a hot humid tropical environment. Journal of Sustainable Agriculture and the Environment 2(2): $168-173$.

Badra, T., 1993. Lagos Spinach (Celosia sp). In Williams, J. T. (ed.) Pulses and vegetables. Chapman and Hall. $2-6$ Boundary Row, London. SE 18 HN. Pp. $131-163$.

Black, H. C., 1992. Silvicultural approaches to animal damage management in Pacific Northwest forests. USDA Forest service, Pacific Northwest Research Station, General Technical Report PNW-GTR - 287, Portland, Oregon.

Brinckman, W. L. and deleeuw, P. N. 1979. The nutritive value of browse and its importance in traditional pastoralism. In Ajayi, S. S., Halstead, L. B. and Taylor (eds.). Wildlife Management in Savanna woodland. Pp. $100-$ 109. London.

Burkill, H. M., 1985. The useful plants of west Tropical Africa. $2^{\text {nd }}$ ed. Royal Botanic Gardens, Kews, U.K.

Chheda, H. R., 1973. Forage Crops Research at Ibadan. 1 Cynodon spp. In Looshi, J. K; Oyenuga, V. A. and Babatunde, G. M. (eds). Animal Production in the Tropics. Pp. 79 - 94. Heinemann Education Books (Nigeria) Plc, Ibadan.

Crowder, L. V. 1973. Pasture Development in Tropical Latin America. In Looshi, J. K; Oyenuga, V. A. and Babatunde, G. M. (eds.) Animal Production 
in the Tropics. Pp. $102-115$. Heinemann Educational Books (Nigeria) Plc, Ibadan.

Devendra, C. 1991. Nutritional potential of fodder trees and shrubs as protein sources in ruminant nutrition. In Speedy, A. and Pugliese $P$. (eds.). Legume trees and other fodder trees as protein sources for livestock. Proceeding of the FAO Expert Consultation held at the Malaysian Agricultural Research and Development Institute in Kuala Lumpur Malaysia, 14 - 18. October 1991.

Devendra, C. and McLeroy, G. B., 1982. Goat and Sheep Production in the Tropics. Longman Group Limited, Longman House, Burnt Mill, Harlow, Essex, UK. Pp. 271.

Dike, M. C., 1992. Tree Regeneration, recruitment and mortality in Nigerian Tropical Moist Forests. Ph.D Thesis, University of Ibadan, Ibadan Nigeria. 235pp.

Dike, M. C., 2001. Flowering and fruiting periodicity of some tree species in southeastern Nigerian rainforest. Global Journal of Pure and Applied Science, 7(4): $647-653$.

Dike, M. C., 2003. Early secondary succession on a mechanically cleared moist forestland in southeastern Nigeria. Journal of Tropical Forest Research, 19(2): $104-116$.

Entwistle, P. V. and Hunter, W. L., 1994. Report on crude fibre Journal ACAC 32: $651-656$.

Faboya, O. O. P., 1983. The mineral content of some green leafy vegetables commonly found in the western part of Nigeria. Food Chemistry. 12 : $213-216$

Grubb, P. I., Turner, I. M. and Burslem, D. F. R. P., 1994. Mineral nutrient status of coastal hill dipterocarp forest and adinandral belukar in Singapore. Analysis of soils, leaves and litter. Journal of Tropical Ecology. 10: $559-577$.

Gupta, B. K, Singh, A. and Malick, N. S., 1991. Effect of feeding dried Leucaena to buffalo and crossbred cow calves. Proceeding of ivth International Rangeland Congress, Montpellier, France.

Hutchinson, J. Dalziel, J. M., 1954 - 1972. Flora of West Tropical Africa $\left(2^{\text {nd }}\right.$ Edition revision edited by $R$. W. J Keay (vol. 1) and F. N. Hepper (vol. 11 and 111). Crown Agents for Oversea Governments and Administrations Millbank, London S. W. I.

Ibeawuchi, J. A. and Akinsoyinu, A. O., 1989. Influence of brewers dried grains on the ruminal volatile fatty acids. VFA production and milk constituents in Zebu cows. Nigerian Journal of Animal Production 21(1): $1-7$.
James, C. S., 1995. Analytical Chemistry of Foods. Chapman and Hall, New York.

Jones, E. W. 1956. Ecological studies in the rainforest of southern Nigeria iv. The Plateaux forest of Okomu Forest Reserve. Journal of Ecology 44: $82-117$.

Kings, R. P., 1996. Biodiversity of Fresh Water Fishes of the Cross River in the Rainforest Belt of Cameroon - Nigeria. In Obot E and Barker, J. (eds.) Proceedings of: Workshop on the rainforest of southeastern Nigeria and southwestern Cameroon Obudu Cattle Ranch and Resort. 20 - 21. October 1996, Jamestown Surplus Limited. Pp. $184-197$.

Milligan, K., Ajayi, S. A. and Afolayan, T. A., 1982. Habitat utilization by wild herbivorous communities in Kainji Lake National Park: Some proposals for range management. In Sanford, W. W. Yesufu, H. M. and Ayeni, J. S. O. (eds.). Nigerian Savanna. The Man and Biosphere State-of-Knowledge Workshop. Nigerian National Man and Biosphere Committee; UNESCO and the Kainji Lake Research Institute held at Kainji Lake Research Institute, April 20 - 24. pp. $271-288$.

Milligan, K. and Sule, B., 1982. Natural Forage Resources and their Dietary value. In Sanford, W. W. Yesufu, H. M. and Ayeni, J. S. O. (eds.) Proceedings of the Man and Biosphere state-of-knowledge workshop. The Kainji Lake Research Institute; New Bussa, April 20 - 24; 1980.

Ngoka, P. C. and Dike, M. C., 2008. Implications of Environmental impact on Tourism utilization of Yankari National Park. Journal of Tourism Research (In press).

Nielsen, F. N., 2001. Boron, Manganese, Molybdenum and other Trace Elements. In Bowman, B. A and Russell, R. M. (eds.). Present knowledge in Nutrition. $8^{\text {th }}$ edition. Pp. $384-400$. International Life Sciences Institute press, Washington, D.C.

Norton, B. W., 1994. Anti-nutritive and toxic factors in forage tree legumes. In Gutteridge. R. C. and Shelton, H. M. (eds.) Forage Tree Legumes in Tropical Agriculture. Pp.202 215. CAB International, Wallingford Oxon. UK.

Olubajo, F. O. 1973. Pasture Research at the University of Ibadan. In Looshi J. K., Oyenuga, V. A. and Babatunde, G. M. (eds.). Animal Production in the Tropics, Pp67 - 78 . Heinemann Educational Books (Nigeria) Plc, Ibadan.

White, F. 1983. The vegetation of Africa UNESCO Paris.

Whitmore, T. C., 1983. Secondary succession from seed in tropical rainforest Forestry Abstracts 44: 767 -779 . 